unlike the Ebers, in date somewhat similar or a little earlier, and its scribe no less careless and incompetent. He was, however, engaged in copying a document of greater scientific value, and probably of greater antiquity than that which was occupying the scribe of the Ebers Papyrus, for there can be little doubt that the original source of the Edwin Smith Papyrus was of the Old Empire. Moreover, the Edwin Smith Papyrus deals with surgical conditions, and especially injuries, while the Ebers is occupied with diseases. Injuries and their treatment lend themselves to clearer descriptions than do the diseases. We thus have in the Edwin Smith Papyrus a document of high value for comparison with certain works of the "Hippocratic Collection" of about twelve centuries later. Without discussion of details it may be said that through the mist of scribal ignorance and misunderstanding we can see in the Edwin Smith Papyrus an author who not only recorded actual case histories, but was seized at times of the spirit of science; that is to say, he records in order to learn something of the workings of the body as distinct from any attempt to treat his patient. Some of his observations, such as that injuries to the brain on one side result in paralysis of the other side of the body, are repeated in the "Hippocratic Collection", and do, in fact, throw light on the nature of physiological mechanism. The Edwin Smith Papyrus - or at least that part of it which survives-is devoted to injuries about the head. It gives us a glimpse--alas! that it should be so dim-of a lost and more ancient scientific literature to which such magnificent treatises as the "Wounds of the Head" and "Fractures and Dislocations " of the "Hippocratic Collection" may well have been related.

For Egyptian mathematics the most important document is the Rhind Papyrus, which was finely edited a few years ago by Prof. T. E. Peet, of Liverpool. ${ }^{5}$ Its age is about that of the Edwin Smith Papyrus, though it is copied from an original of the nineteenth century B.C. It professes to be a 'guide for calculation'. Apart from simple rules for giving the areas of figures enclosed by right lines, we have the measure of a circle from which an estimate of $\pi$ as 3.16 can be deduced, and a calculation with reference to the proportions of pyramids. In this last a certain relation which, as the Papyrus says, "makes the nature of the figure ", is deduced from the side of the square base and vertical height or per-em-us as the Papyrus calls it. The word per-em-us is doubtless the source of the Greek word pyramis and our pyramid. The problem clearly links up with the mathematical triumph of Thales in deducing the height of a pyramid from its shadow.

The last scientific document of Egyptian origin to be considered is the Moscow Papyrus, which was only published in full by Prof. Struve a few months ago. ${ }^{6}$ It is of the Middle Kingdom and thus older than the others. It contains the determination of the volume of a truncated pyramid and the area of a hemisphere. ${ }^{7}$ Both are correct, the latter on the basis of the Egyptian value for $\pi$ as $3 \cdot 16$. It yet remains to be seen whether these determinations are based on general formulæ-as is believed to be the case by Prof. Struve--or whether they are empirically obtained. If the former, it will be necessary to rewrite the history of ancient science and with it much of ancient philosophy.

The rationalisation of the Greek intellect within a very few centuries has always appeared something of a miracle--an epiphany. On the other hand, an ancient and slowly disintegrating scientific tradition in Egypt or in the Near East would fit in well with what we know of the early history of Greek science. Whether such traditions existed is a question of fact which can only be solved by the Egyptologists or Assyriologists. In the meantime, the Rhind, the Edwin Smith, and the Moscow Papyri have made such a view less fantastic than would have appeared to be the case ten years ago.

1 The more important works of the "Hippocratic Collection" a re being edited by Mr. W. H. S. Jones and Mr. E. T. Withington for the Loeb Jibrary. For a contelete critical version we still depend on Emil Littrés "Quvres complètes d'Hippocrate" in 10 volumes (T'aris, 1839-61).

"C. N. Cochrane, "Thucydides and the Science of History" (Oxford University Press, 1929).

${ }^{3}$ An excellent summary of Greek mathematics has recently been prepared by Sir T. L. Heath, "A Mamual of Greek Mathematies" (Oxiord: "the ('larendon Press, 1931).

"J. H. Breasted, "The Edwin Smith Surgieal Papyrus", 2 vols. (Lniversity of (hicago Press, 1931).

`T. E. Pect, "The Rhind Mathematical Pamsrus" (Liverpool, 1923). Another edition was produced for the Mathematical Association of America, $1927-29$, by A. B. Chace, J. S. Bull, and H. ${ }^{3}$. Manning, with a bibliography of Egyptian and Babylonian Mathematies by $R$. C. Archibald.

A W. W. Struve, “ Mathematischer Papyrus des Staatlichen Museums der schönen Künsten in Moskau" (Quellen und Studien zur Geschichte

der Mathematik ; Abt. A, Quellenband 1), Berlin, 1930 .
7 The Moscow Papyrus is discussed by Battiscombe Gunn and T. Eric Peet. "Four Gew Paprirus is discusser by Battiscombe Gunn and T. Eric Peet, "Four (icometrical Problems from the Moscow Mathematicial Papyrus", Journal of Egyptian Archreology, 15, p. 167, Nov. 1929; and Kurt Vogel, "The Truncated Pyramist in Egyptian Mathematies" Journal of Egyptian Archaology, 16, p. 242, Nov, 1930. The work of Archaology, 17, p. 154. May 1931 .

\title{
Population Problems.
}

THE second general assembly of the International Union for the Scientific Investigation of Population Problems met in the rooms of the Royal Society of Arts on Monday, June 15, the chair being taken by the president, Prof. Raymond Pearl. Delegates of ten nationalities were present.

During the opening session the president reviewed the work of the Union during the three years of its existence, and claimed, with reason, that the progress made could be regarded as gratifying. Fourteen countries already have National Com- mittees, which function with varying degrees of intensity, whilst in still other countries (Czechoslovakia, Greece, Poland) National Committees are in process of organisation. There are three International Research Commissions receiving funds from the Union and dealing respectively with population and food supply, differential fertility, and the vital statistics of primitive races. In addition, grants have been made to many individuals for investigations which fall outside the scope of these Commissions. Sixty-four per cent

No. 3218, Vor. 128] 
of all moneys expended is allocated to research. Nine numbers of the official bulletin have been published.

Election of officers took place, and Sir Charles Close succeeds Prof. Raymond Pearl as president of the Union.

During the morning sessions of the following three days, various modifications of the statutes and regulations shown to be desirable by the experience gained during the past three years were made. The afternoon sessions were devoted to the reading of scientific papers.

Prof. J. D. Black, chairman of the commission dealing with population and food supply, outlined a scheme which had been prepared to serve as a basis for the making of an inventory of the work already done on this particular subject and as a guide in the planning of future research. Prof. Jens Warming, of Copenhagen, discussed the trends in agricultural production in Denmark. In his country the increase of the harvest is greater than the growth of population, and if there should be a shortage of one kind or source of food (for example, grain, as was the case during the War) it is a relatively simple matter to adjust this by curtailing the amounts used for animal fodder.

Prof. P. K. Whelpton, of the Scripps Foundation, said that population increase was declining rapidly in the United States, being 9 per cent in 1930 as against 18 per cent in 1920. Consequently, the age composition had changed considerably in the last decade. The number of children under five has actually declined, while the number of persons over fifty has increased about 25 per cent. This slower growth and trend toward a nation of elders should have marked effects on economic, social, and political life, checking expansion and making for greater conservatism.

Prof. A. L. Bowley, of the London School of Economics, dealt with some economic aspects of the tendency of population in Great Britain. $\mathrm{He}$ showed that during the past twenty years wages have increased, especially so in the case of town labourers; so much so that in 1929 such a man in regular work had a wage sufficient to provide the bare necessities for a family of four children under fourteen years of age. Poverty in urban districts is due, not to low wages, but to illness, age, unemployment, incapability, death, or absence of the natural bread-winner. During the same period there has been a progressive change in the constitution of the family. The falling birth-rate since 1914 has resulted in a decrease in the number of childbearing women, a fall in the number of children, and an increase in the number of old people. With the rise of the real wage and the reduction in the number of children per family, future generations will live in an environment progressively more and more favourable for satisfactory development. Smaller families mean better housing conditions and less competition for employment.

Dr. Karl Edin, of Stockholm, reported further on his study of differential fertility among the social classes. His figures show that in this city fertility tends to rise and not to fall with increase in income. Furthermore, sterility is greater amongst the poor couples. Prof. Eugen Fischer, of the Kaiser Wilhelm Institut für Anthropologie, reported on Dr. Muckermann's studies on differential fertility of the agricultural workers and university teachers in Germany. The conclusion to be derived from this study is that a social group, selected on the basis of intellectual achievement, is incapable of maintaining its numbers. Dr. L. I. Dublin, of the Metropolitan Life Insurance Company of New York, read a paper on the outlook for the American birth-rate. He concludes that the decline of the birth-rate is universal, and results primarily from voluntary control of conception and not from reduced fertility. $\mathrm{He}$ assumes that the population of the United States will become stationary in the course of the next generation or two with a birth-rate of 14.28 per thousand, and that, having reached this stationary stage, it will then proceed to decline at a rate that will reduce it to one-half in 300 years, in 161 years, in 108 years, or in 80 years, according to whether or not certain variables operate.

Prof. C. B. Fawcett dealt with some factors of population density. He estimates that the total habitable land area of the world is about $50,000,000$ square miles and the approximate population of the world about 2000 million. The mean density of population over all the inhabited land of the world is therefore about forty persons per square mile. The actual distribution of population over the land varies from 680 per square mile in Belgium to $2 \cdot 2$ in Australia. It is difficult, perhaps impossible, to enumerate all the factors causing this wide variation in local densities, but amongst the most important are the following - natural resources of the land, mineral wealth and power, geographical location. Developments in modern transport have led to a readjustment of the balance between local fertility and density of population. Products gained locally are, in the great majority of cases, not used locally, but serve to maintain the population of distant regions ; and therefore the age-old tendency for density of population to increase in proportion to fertility of the land has lost much of its strength. In some countries we even find that increase in food production locally is accompanied by a decrease in the agricultural and rural population. There is no indication that the fertile regions of the New World are likely to become the home of densely crowded peasant populations comparable to those of China. Prof. Fawcett argued that in Britain the Poor Laws during the last century and the Unemployment Insurance to-day both have had the unforeseen and undesirable result of restricting freedom in the matter of internal migration. The growth of the town-planning movement and of the consciousness of the need of a well-considered country-planning in many lands indicates the likelihood of a far greater governmental interference in the future.

Prof. J. W. Gregory spoke on some effects of current migration restrictions. During recent years there has been an almost complete suppression of immigration on the part of those countries 
which formerly received the bulk of European emigrants. One effect of such restriction in the United States is labour shortage, resulting in an increased internal migration of negroes and Mexicans. Higher wages and improved hygienic and social conditions tend to increase the duration of life and reduce the infantile mortality of the negro, and this, with the absence of European immigration, must raise the proportion of negroes in the population. This view was not accepted by several of the American delegates, one of whom instanced the fact that birth control clinics were now being opened and considerably used by the negro population of the Harlem district of New York.

Dr. G. W. Kosmak dealt with the position of the obstetrician in relation to certain aspects of the population problem. He expressed the opinion that certain developments in the practice of obstetrics at the present time may have a not inconsiderable effect in reducing the birth-rate; for example, the increase in operative deliveries, which result in a higher mortality, and at the same time undoubtedly produce increased sterility through infection. He pointed out that the dread of maternal mortality played its part in the encouragement of women to have recourse to birth control.

In a paper on the future of the Belgian population, Prof. Baudhuin, of the University of Louvain, concludes that the population is now approaching its maximum, which it will attain about 1940 , when it will number $8,110,000$; and that after this there will be a gradual decline, so that in the year 2000 it will be only $5,760,000$.

Further interesting papers on this subject were presented by Mr. Lotka, Dr. Wicksell, and others, and, in the concluding sessions, papers dealing with the broader biological aspects of the population problem were presented by $\mathrm{Mr}$. Elton, who dealt with the cyclical variation in the numbers of lemming, Arctic fox, and field mouse population, and by Mr. J. A. Fraser Roberts, who discussed the significance of the results of mass selection in the improvement of the breeds of domesticated animals.

The function of the Union is to discuss such matters as the above dispassionately and scientifically, and it is doing its best to carry out this duty, though somewhat hampered by want of funds. Much of the money which has hitherto been spent on the work of the Union has been presented by generous individuals and institutions in America it is the turn of other countries to follow such a good example, especially as an excellent opportunity now offers itself. The chairman of the American National Committee, Dr. Louis I. Dublin, informed the general assembly that certain sources in the United States would be prepared to pay to the Union the sum of 5000 dollars a year, for three years, on the condition that a similar total sum was presented to the Union by individuals, or institutions, in other countries. This offer was gratefully accepted by the general assembly. Will not those who are interested help by their subscriptions to make this generous offer available? Subseriptions may be sent to the General Secretary, International Population Union, 46 Catherine Street, Westminster.

Prof. Eugen Fischer extended an invitation, which was unanimously accepted, to the Union to hold its third general assembly in Germany in 1934 .

\section{Obituary.}

Mr. W. F. Denning.

$\triangle \mathrm{S}$ announced in Nature for June 20, the veteran A astronomer, Mr. William Frederic Denning, died at Bristol, mainly as the effect of the weakness of age, on June 9 last.

Mr. Denning was world-famous, having a reputation based on careful and assiduous use of the telescope, but known more especially for his nakedeye observation of the flight of meteors and his deduction from them of radiant points that form a large part of contemporary knowledge of this byway of science.

Denning was born on Nov. 25, 1848, at Redpost, near Radstock, in Somerset. When quite a boy the aspect of the night sky had an attraction for him, and at the age of seventeen he became possessed of a $4 \frac{1}{4}$-inch refracting telescope, which was followed in 1871 by a 10 -inch reflector, with which his more important observations were made. At the period when Denning began his astronomical career, the medium for publications relating to the science was the Astronomical Register, a monthly periodical started in 1863, in which astronomers made public their views and observations; and to this Denning began to contribute in 1868, his earliest communications being on the surface of Jupiter and the appearance of its satellites, and others on the visibility of Mercury with the naked eye, which was a subject to which he gave much attention throughout his life. A letter in the issue of December 1868 on his observation of the Leonid meteors of that year is interesting as foreshadowing the main work of his life. In 1869 an organisation known as the Observing Astronomical Society was formed under the auspices of the Register, which numbered more than forty active members in its second year, and of this Denning was secretary and treasurer. The pages of the periodical show how well he fulfilled the duties of his office during the few years of the existence of the Society. He was president of the Liverpool Astronomical Society in 1887-88.

Denning did not become a fellow of the Royal Astronomical Society until June 1877, but he contributed several short papers to the Monthly Notices before that date, with Mr. Proctor, Mr. Main, or some other as sponsor-among these being notes on the visibility of Mercury as a naked-eye object in the twilight, and of the possibility of seeing Jupiter and Venus in sunshine, which he said he was frequently able to do. The majority of them, however, were records of his observation of luminous

No. 3218, Vor. 128] 